\author{
Konrad Knoch \\ Uniwersytet Gdański/Europejskie Centrum Solidarności \\ ORCID: 0000-0003-4602-4481
}

\title{
„Przegląd Polityczny” w latach 1989-2000. Cz. 3. Liberalna rewolucja
}

\begin{abstract}
Streszczenie
W artykule scharakteryzowano, w jaki sposób „Przegląd Polityczny” chciał patronować rewolucji liberalnej w Polsce. Opisano debaty, toczące się na łamach pisma na temat kapitalizmu, postulowanych reform, głównie w wymiarze ekonomicznym. Dokonano analizy zjawiska prywatyzacji, decentralizacji oraz rozliczeń, jakich dokonywano z liberalną rewolucją u Polsce u I połowie lat 90. XX wieku. Przedstawiono również ewolucję i zmianę profilową pisma. Na koniec dokonano podsumowania roli i znaczenia „Przeglądu Politycznego” oraz oceniono jego dorobek publicystyczny.
\end{abstract}

Słowa kluczowe: historia prasy gdańskiej, historia polskiego liberalizmu, liberalizm, prywatyzacja, „Przegląd Polityczny”.

\section{"Political Review" in the years 1989-2000. Part 3. Liberal revolution}

\begin{abstract}
The article describes how the "Political Review" wanted to promote the liberal revolution in Poland. Debates on capitalism, postulated reforms, mainly in the economic dimension included in the Review are described. The phenomenon of privatization, decentralization and settlements with the liberal revolution in Poland in the first half of the 1990s is also analysed. The evolution and profile change of the magazine is also presented. At the end, the role and significance of the "Political Review" is summarized and its journalistic achievements are assessed.
\end{abstract}

Keywords: history of Gdansk press, history of Polish liberalism, liberalism, Political Review, privatization.

\section{Wprowadzenie}

W pieruszej części poświęconej „Przeglądowi Politycznemu”, zamieszczonej u numerze 3 czasopisma „Media Biznes Kultura” opisałem problemy organizacyjno-uydaunicze liberalnego tytułu w pierwszej dekadzie po upadku komunizmu w Polsce ${ }^{1}$. Z kolei w części drugiej, zamieszczonej w numerze 4, omówiłem ideologię liberalizmu

\footnotetext{
${ }^{1}$ K. Knoch, „Przeglad Polityczny” w latach 1989-2000. Cz. 1. Problemy organizacyjno-wydawnicze, „Media Biznes Kultura” 2017, nr 2(3), s. 57-70.
} 
przedstawianą na łamach tytułu, jak róunież tło związane z poustaniem i funkcjonowaniem Kongresu Liberalno-Demokratycznego. Starałem się odpowiedzieć na pytanie, na ile czasopismo było organem gdańskich liberałów, a na ile niezależnym tytułem będącym miejscem liberalnej debaty. Wreszcie, w jaki sposób kształtowało ideologię liberalizmu².

W tym tekście dokonałem ponounie analizy treści 34 numerów „Przeglądu Politycznego". Na potrzeby badania przejrzałem całą zawartość periodyków. Wyodrębniłem pięć zakresów tematycznych, które są zuiązane z ideologią liberalizmu i do każdej z nich przyporządkowałem teksty, a następnie dokonałem ich omówienia. Skupiłem się na praktycznym wymiarze liberalnych koncepcji prezentowanych w „Przeglądzie Politycznym” - postulatach reform, prywatyzacji, decentralizacji, ocenie reform gospodarczych w latach 90. XX wieku i funkcjonowaniu polskiego kapitalizmu. Pominąłem wątki dotyczące spraw zagranicznych, geopolityki, kultury, szerszego kontekstu społecznego czy lokalnego. Podobnie jak u poprzednim tekście chciałem zueryfikować tezę, czy „Przegląd Polityczny” był partyjnym organem, czy wypracował jakiś program o charakterze liberalnym, a jeśli tak, to na ile był on konkretny. Chciałem róunież sprawdzić, czy myśl prezentowana na łamach czasopisma podlegała zmianom. Na koniec dokonałem całościowej oceny prezentowanych zagadnień.

Problematyka gospodarcza nieprzerwanie pojawiała się w omawianym okresie na łamach „Przeglądu Politycznego”. Wielokrotnie tematykę tę poruszano w dziale „Idee”. Niektóre numery zawierały podtytuł-pytanie na okładce: Jaki kapitalizm? Zajęły się szczegółowo analizą stanu polskiej gospodarki, reform ekonomicznych, poruszyły sprawę kapitalizmu. Starały się odpowiedzieć na pytania: jaki ma być polski model gospodarczy, jakie rozwiązania konkretnych problemów byłyby dla Polski najlepsze.

\section{Ideologia kapitalizmu}

Analizy dotyczące ideologii kapitalizmu zaczęły się od przywołania filozofii Ludwiga von Misesa. Zamieszczenie fragmentu jego artykułu zatytułowanego właśnie „Kapitalizm” miało rozpocząć dyskusję na łamach „Przeglądu Politycznego” na temat polskiego modelu gospodarczego. W tekście przedstawiono historię, proces poustawania kapitalizmu. Mises przypominał, że to Karol Marks stuorzył to pojęcie i że mylił się we wszystkim. Kapitalizm według czołowego neoliberała polepszył „,̇ałosne warunki egzystencji”. Jego zdaniem ci, którzy pracowali w fabryce początkowo w dość ciężkich warunkach, wcześniej w jeszcze gorszych żyli u boku arystokracji. Dzięki kapitalizmowi w latach 1760-1830 ludność Anglii się podwoiła, a stopniowo robotnikom żyło się coraz lepiej i zyskiwali nowe prawa. Gdy zgromadzono kapitał, pensje rosły, związki działały coraz skuteczniej.

${ }^{2}$ K. Knoch, „Przegląd Polityczny” w latach 1989-2000. Cz. 2. Liberalna rewolucja, „Media Biznes Kultura” 2018, nr 4, s. 97-109. 
Kapitalizm był identyfikowany $\mathrm{w}$ tym artykule $\mathrm{z}$ produkcją masową, wolnym rynkiem, wolną konkurencją ${ }^{3}$. Ale poza charakterystyką Mises miał jakby przekonać czytelników do kapitalizmu, który w Polsce stawiał utedy pierwsze kroki. Autor tuierdził, że u tym systemie to klient jest panem, rządzi, a każdy służy konsumentowi jak najlepiej. W kapitalizmie to klient-konsument decyduje o tym, co utrzyma się na rynku. Zatem w praktyce każdy z nas ma upływ na rynek: to my płacimy gażę guiazdom Hollywoodu, kupując bilety! Brzmiało to jak reklama kapitalizmu.

W podobnym tonie wypowiadał się Peter Berger amerykański socjolog, ekonomista, który napisal, że: „Rewolucja przemysłowa stanowi historyczne osiągnięcie kapitalizmu, zaś przemysłouy kapitalizm stworzył największe moce wytwórcze w dziejach ludzkości. Dziś zapewnia to optymalne ramy dla mocy wytwórczych nowoczesnej technologii”. Potwierdził jednocześnie wywody Misesa: „Rozwinięty kapitalizm stworzył największy w historii materialny standard życia dla szerokich mas" ${ }^{\text {. }}$ W tym samym numerze, u skromnym jednostronicowym tekście padła definicja kapitalizmu, za który autor uznał gospodarkę prywatną, prywatną ułasność u gospodarce ${ }^{6}$. W podobnym duchu pisał prezes zarządu Rafinerii w Gdańsku: „Sprawne funkcjonowanie nowoczesnego kapitalizmu opiera się na prywatnej ułasności i wolnej wymianie towarów"7. Podobnie stwierdzał kolejny autor, definiując kapitalizm jako własność i rynek ${ }^{8}$.

Na łamach „Przeglądu Politycznego” pojawiły się także teksty opisujące elementy kapitalizmu. Artykuły te ukazywały u ten sposób różnicę między polskimi warunkami, polską rzeczywistością ekonomiczną, społeczną a rzeczywistością zachodnią. Dodatkowo szukano jakiegoś fundamentu, podstawy opartej o wartości. W wielu miejscach omawiano koncepcje Webera dotyczące zagadnienia pracy w katolicyzmie i protestantyzmie. Ireneusz Krzemiński w jednym ze swoich tekstów podsumował, że nie można sobie uyobrazić kapitalizmu bez etosu protestanckiego9.

Również pismo wskazało na różnice procesów historycznych. Podczas rozmowy redakcji z Adamem Jezierskim ten ostatni stuierdzil, że kapitalizm to nie tylko Marks i wartość dodatkowa z XIX wieku, lecz także koncepcje Fernanda Braudela i XV-wieczna Florencja, w której kształtował się kapitalizm: z nadwyżką dochodów, inwestycjami, kredytem, uekslem, księgowością ${ }^{10}$.

Jednak w „Przeglądzie Politycznym” doskwiera brak uniknięcia w istotę kapitalizmu, wytłumaczenia, czym on tak napraudę był i jest. Brakuje szerszych analiz, kontekstów. Teksty są w istocie nie o nim, a jego skutkach, historii, znaczeniu, zasługach. Są też

\footnotetext{
${ }^{3}$ L. von Mises, Kapitalizm, „Przegląd Polityczny” (dalej cyt.: PP) 1992, nr 1-2 (14-15), s. 52-60.

4 P.L. Berger, Róg obfitości, PP numer specjalny 1993, s. 87-97.

${ }^{5}$ Ibidem, s. 96. Autor na potwierdzenie przytoczył krzywą Kutznesa w kształcie U, która ukazywała najpieru nierówności związane z rozwojem kapitalizmu, a potem uyróunywanie i stały wzrost jakości życia uczestników życia gospodarczego.

${ }^{6}$ P. Aleksandrowicz, Kapitalizm w Polsce, PP numer specjalny 1993, s. 110.

7 W. Dyrka, Wyzwanie i szansa, PP 1994, nr 26, s. 40.

${ }^{8}$ M. Zieliński, Czy istnieje w Polsce kapitalizm, PP 1994, nr 25, s. 34-37.

${ }^{9}$ I. Krzemiński, Etyka i biznes, PP 1993, numer specjalny, s. 131-132; P.L. Berger, Etyka i polityka, op. cit., s. 20; D. Filar, Duchowe korzenie kapitalizmu, PP 1994, nr 25, s. 59-61.

${ }_{10}$ Rozmowa z A. Jezierskim, Kapitat, Państwo, Kultura, PP 1993, nr 21/22, s. 86-90.
} 
bardzo powierzchoune i jednostronne. Czasem zabrakło także wyraźnego rozgraniczenia między kapitalizmem a liberalizmem, a oba pojęcia się mieszają. Na łamach „Przeglądu Politycznego”, mówiąc w skrócie „wygłoszono pochwałę dla kapitalizmu”.

\section{Ocena reform gospodarczych III RP}

Już pierusze numery przystąpiły do swoistej ofensywy mającej na celu bardzo szczegółową charakterystykę polskiej gospodarki. Głównym jej elementem była ocena dorobku reformatorskiego polskich rządów, a wraz nią promocja reform gospodarczych. Wypowiedzi było całe mnóstwo. Artykuły do „Przeglądu” pisali dziennikarze, politycy, naukowcy, profesorowie oraz liderzy środowiska gdańskich liberałów. Tematyka ta uyraźnie zdominowała pierwsze numery pism po roku 1991. Ukazał się nawet numer specjalny w 1993 roku, który był miejscem ożywionej dyskusji gospodarczej, ekonomicznej.

Zasadniczo narzekano na brak konsekwencji reformatorów. Gadomski był rozczarowany zmarnowaniem programowym 10 lat w opozycji. Pochwalił reformy Balcerowicza, które widział jednak jako wstęp do reform strukturalnych. Jednocześnie skrytykował jego nadmierny optymizm, który się rozminął w starciu z dominacją przedsiębiorstu państwowych ${ }^{11}$.

Pismo podobnie jak w ostatnich dwóch numerach podziemnych promowało zjawisko „Nowej przedsiębiorczości”. Patronowało poustającym nowym firmom, zułaszcza małym i średnim oraz nowej klasie średniej. „Przegląd” wyliczał niedogodności, na jakie był narażony początkujący przedsiębiorca. Szczegółowej analizy dokonywali członkowie Instytutu Badań nad Gospodarką Rynkową (dalej cyt.: IBNGR) Maciej Grabouski i Przemysław Kulawczuk. Pisali o kłopotach z uzyskaniem kredytów, istnieniu czarnego rynku kredytowego, problemach z egzekucją należności zułaszcza przez tych, którzy współpracują z sektorem publicznym, zmniejszeniu się rynku dla małych i średnich przedsiębiorstu, określeniem sfery zbytu. Obaj uskazali na „amatorską” działalność wielu przedsiębiorców, którzy na przykład: reklamę uykorzystują powierzchownie ${ }^{12}$, brak profesjonalizmu, samouctwo, brak etyki pracy, brak lojalności, poszanowania praw autorskich i uynikająca z tego wszystkiego niska kultura w zarządzaniu pracounikami ${ }^{13}$.

Pismo uskazywało na bardzo ważny, nierozwiązany problem bezrobocia, pisało o trudniejszej sytuacji kobiet, specyfice regionalnej bezrobocia ${ }^{14}$. „Przegląd Polityczny” był "dobry” w stawianiu diagnoz, ale przez całą dekadę nie podał żadnych recept na przezuyciężenie problemów, o których pisał. Do roku 2000 nie mamy tekstu ściśle programowego, z konkretnymi propozycjami rozwiązań w sferze naprawy gospodarki czy szerszych analiz na temat bezrobocia, jego przyczyn, skutków.

${ }^{11}$ W. Gadomski, Rewolucja liberalna, PP 1991, nr 2/14, s. 8-11.

${ }_{12}$ M.H. Grabouski, P. Kulawczuk, Polski Sektor Prywatny, PP 1992, nr 3/16, s. 66-70.

${ }^{13}$ M.H. Grabouski, P. Kulawczuk, Dlaczego pakt z kapitałem?, PP 1993, numer specjalny, s. $56-59$.

14 J. Witkouski, Rynek pracy w Polsce w latach 1990-92, PP 1993, numer specjalny, s. 60-63. 
Oprócz stawiania często dramatycznych diagnoz, analiz, „Przegląd Polityczny” szukał odpowiedzialnych za taki stan rzeczy. Często wskazywano na młodą i nieukształtowaną polską demokrację, rozbicie polityczne, brak konstytucji, powolną legislację, brak narodowej polityki przemysłowej, ograniczoną rolę banków, brak kapitałów, opóźnioną prywatyzację $^{15}$. Analityk z IBNGR Jan Szomburg stwierdzał, że: „Główną barierą transformacji gospodarki okazała się słabość systemu politycznego" oraz braki: własności prywatnej i partii, które owocowały słabością państwa. Należało jego zdaniem inwestować $w$ partie polityczne ${ }^{16}$. Jacek Merkel nieco żartobliwie scharakteryzował polską klasę polityczną, która chodzi w krótkich spodenkach i której do mundurka maturalnego wiele brakuje ${ }^{17}$. Redakcję niepokoił $w$ wielu miejscach wzrost oddziaływania urzędników na sferę gospodarki, rosnący deficyt budżetowy, brak decentralizacji.

Szomburg dostrzegł problem genetyczny u samej „Solidarności” - brak poglądów na prywatyzację i reprywatyzację, co opóźniało jego zdaniem rozwój normalnego systemu politycznego. Ubolewał, że w Polsce, zamiast przyjąć rozwiązania na poziomie ogólnym, to na przykład decyzja o prywatyzacji wymagała zgody załóg i dyrekcji, co powodowało tysiące mikro-konfliktów ${ }^{18}$.

Ale najbardziej za opóźnienia czy uręcz zaniechania reform gospodarczych dostało się „koalicji ustecznictua gospodarczego” Sojusz Lewicy Demokratycznej/Polskie Stronnictwo Ludowe (SLD/PSL), która przejęła władzę w Polsce w 1993 roku ${ }^{19}$. Widziano w tym groźby, potem zrealizowane, recydywy socjalizmu w gospodarce centralizacji, interwencjonizmu, pozostawienia „gospodarki narodowej”, ustrzymania prywatyzacji: stabilizacji niejasnej roli państwa w gospodarce, wysokiej stopy inflacji ${ }^{20}$. Pisano o kapitalizmie państwowym SLD/PSL, tuorzeniu holdingów (np. Ciech), protekcjonizmie, dużej redystrybucji dochodów przez budżet państwa, co oznaczało dla pisma nieefektyuność, korupcjogenność - rozdaunictuo rad nadzorczych ${ }^{21}$. Gadomski pisał o Rzeczpospolitej koncesjonowanej ${ }^{22}$, a prof. Andrzej Rychard o „mechanizmach koncesyjno-przyznaniouych i neokorporatyzmie”. Postawił tezę, że: „Interwencjonizm i etatyzm wynika z chłopskości polskiej kultury przemysłowej i politycznej”’3.

Eugeniusz Mokrzycki w 1994 roku dramatycznie stwierdzał: „Obecny układ tej sceny społecznej, politycznej dominacji wielkoprzemysłowej klasy robotniczej i chłopstwa, jest praktycznie rzecz biorąc, gwarancją stagnacyjnego wygasania reformy i odbudowywania dawnej struktury interesów grupouych"24.

15 M. Marbot, Przyśpieszyć przemiany rynkowe, PP 1993, numer specjalny, s. 86; Rozmowa z J. Merklem, Polityka karmi się sloganami, PP 1993, numer specjalny, s. 32-36.

16 J. Szomburg, Polityczna próżnia barierą transformacji gospodarki, PP 1992, nr 1-2/14-15, s. $61-65$.

17 Rozmowa z J. Merklem, Polityka karmi się sloganami, op. cit., s. 34.

18 J. Szomburg, Polityczna próżnia bariera transformacji gospodarki, op. cit., s. 61-65.

19 J. Winiecki, Na rozstaju dróg, PP 1993, nr 21/22, s. 90.

${ }^{20}$ W. Wilczyński, Nieporozumienia wokót gospodarki rynkowej, PP 1994, nr 23, s. 76-78.

21 J. Szomburg, Trzy wizje ustroju, PP 1994, nr 25, s. 38-41.

${ }^{22}$ W. Gadomski, Rzeczpospolita koncesjonowana, PP 1994, nr 25, s. 42-44.

${ }^{23}$ Ludzie i instytucje, Rozmowa z prof. A. Rychardem, PP 1994, nr 26, s. 37.

${ }^{24}$ E. Mokrzycki, Na rozdrożu, PP 1994, nr 25, s. 51. 
Po 1994 roku masowość artykułów o tematyce gospodarczej ustępuje skromnej, pojawiającej się dość regularnie rubryce zatytułowanej: „Gospodarka”. Zazuyczaj zamieszczano w niej kilka artykułów (zazuyczaj dwa), nieprzekraczających w sumie kilkunastu stron (zazwyczaj kilku). Nie były to jednak wielkie projekty czy wizje gospodarcze, promowanie nowych rozwiązań. Były to raczej teksty analityczno-krytyczne, odnoszące się do sytuacji gospodarki polskiej i wolnego tempa przemian. Głóuny ciężar krytyki skierowano na koalicję SLD/PSL. Regularnie pisano o wzroście redystrybucji środków przez budżet, wzroście obciążeń podatkouych, malejącej konkurencyjności i inwestycjach zagranicznych, braku restrukturyzacji „molochów” państwouych, które generują gigantyczne straty, o praktykach monopolistycznych, rosnących kosztach długu publicznego, o spowolnieniu prywatyzacji i jej fiskalnym znaczeniu. Zarzucono brak impulsu transformacyjnego, brak wykorzystania wysokiego PKB, a przy jednoczesnym wygasaniu koniunktury, brak mobilizacji punktów wzrostu ${ }^{25}$. Bardzo często narzekano na zaniechanie reform strukturalnych: edukacji, ubezpieczeń, zdrowia, sfery budżetowej, rolnictwa ${ }^{26}$. Prym w oskarżeniach wiedli Janusz Lewandouski i Maciej Zieliński. Ten pierwszy zapytywał z rozgoryczeniem: „słusznie pyta opozycja, jeśli nie teraz reformować kiedy tłuste lata, to kiedy?"27. Zieliński przypominał, że wzrost nie jest dany raz na zawsze ${ }^{28}$.

Szczegółowo opisywano zjawisko uwłaszczenia nomenklatury, która przekształciła się w klasę kapitalistów, by następnie pourócić do polityki i władzy. Zagraniczni analitycy na łamach „Przeglądu Politycznego” ostrzegali, że: „Nomenklaturouy kapitalizm uniemożliwia ewolucję korporacyjnego zarządzania, które jest niezbędne, jeśli Europa Wschodnia ma się przyłączyć do gospodarki światowej" ${ }^{29}$. Kilkukrotnie poruszano groźbę przejścia Polski u stronę latynoamerykańskiej symbiozy władzy i biznesu, biurokratyzacji gospodarki i korupcji ${ }^{30}$. Jednakże z nadzieją w przyszłość patrzył Henryk Domański: „W ostatecznym rachunku problem usunie demografia - procesy starzenia wyeliminują nomenklaturę z szeregów biznesu" ${ }^{1}$. W kolejnych artykułach z działu „Gospodarka” poruszano (poza podobnymi zagadnieniami ${ }^{32}$ ) dodatkowo sprawę deficytu w handlu z zagranicą, rosnącego deficytu budżetowego.

W dziesięć lat po historycznych już reformach Balcerouicza „Przegląd Polityczny” przedrukował wywiad Lewandouskiego zamieszczony w „Rzeczpospolitej”, który ubolewał, że Polska „po 10 latach jest nadal państwem socjalnym do granic możliwości

${ }_{25}$ J. Lewandouski, Gospodarka 95, PP 1995, nr 27/28, s. 24-26; M. Zieliński, Bez złudzeń, PP 1995, nr 27/28, s. 26-28.

${ }^{26}$ J. Lewandouski, Na ręcznym hamulcu, PP 1995, nr 27/28, s. 29-30; idem, Na rozdrożu, PP 1996, nr 30, s. 33; A. Voigt, Gospodarka 97, PP 1997, nr 33/34, s. 22-24.

27 J. Lewandowski, Gospodarka 96, PP 1996, nr 30, s. 30-32.

${ }^{28}$ M. Zieliński, 1996 - rok ostatni dynamicznego wzrostu, PP 1997, nr 33/34, s. 24-26.

${ }^{29}$ R. Frydman, K. Murphy, A. Rapaczyński, Kapitalizm z twarza towarzysza, PP 1996, nr 31, s. 46-57.

30 J. Winiecki, Powyborcze perspektywy gospodarki, PP 1997, nr 35, s. 10-13.

${ }^{31}$ H. Domański, Nomenklatury w krajach postkomunistycznych, PP 1997, nr 35, s. 52-55.

${ }^{32}$ M. Zieliński, Gospodarka 98, PP 1998, nr 36, s. 34-36; M. Gronicki, Rok 1999: szanse i zagrożenia, PP 1998, nr 39, s. 24-25; M. Zieliński, Gospodarka 2000, PP 2000, nr 43, s. 30-32. 
polskich podatników. Przedsiębiorczość jest gnieciona ciągle nowymi przepisami i cię-

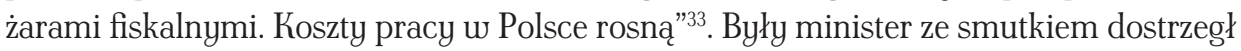
kontynuację niekorzystnych wzorców przez koalicję Akcja Wyborcza Solidarność/Unia Wolności (AWS/UW), na przykład obsadzanie uszystkich stanowisk „swoimi”.

Przejęcie władzy przez koalicję AWS/UW przyniosło jednak niewielki wzrost nastrojów i ocen pozytywnych. Donoszono o spadku bezrobocia, wysokim PKB rzędu 5\%, niskiej jednocyfrowej inflacji i w końcu, o 10 lat za późno, reformie emerytalnej ${ }^{34}$.

Jeśli by się przyjrzeć uważnie uszystkim zarzutom stawianym na łamach „Przeglądu Politycznego”, to na pieruszy rzut oka są one słuszne, do bólu racjonalne, a postulaty koniecznych zdaniem redakcji zmian jak najbardziej zasadne. Podobnie jak w przypadku kapitalizmu ocena jest jednak mocno jednostronna (nie daje się słowa drugiej stronie) oraz dość powierzchowna. Czuć róunież wyraźną niechęć u wymiarze politycznym do koalicji SLD/PSL, niezależnie od racjonalnie kierowanej krytyki.

\section{Problem prywatyzacji}

Pouszechnie na łamach „Przeglądu Politycznego” padało hasło: prywatyzować! Prywatyzacja bowiem miała być nadzieją na restrukturyzację molochów państwouych, unowocześnienie produkcji, jakość i sprowadzenie kapitału ${ }^{35}$. W czasach, gdzie partie i rządy są niestabilne, gospodarka miała stać się podstawą budowania normalności, a solidne podstawy gospodarki można było uzyskać przede uszystkim poprzez prywatyzację ${ }^{36}$. Pismo zamieściło artykuły o ogromnym znaczeniu tego procesu. W numerze specjalnym znalazły się także opinie zachodnich ekonomistów o prywatyzacji w Europie Środkowowschodniej, przedstawiające różne modele prywatyzacyjne ${ }^{37}$.

Pojawiło się wiele głosów, które z niepokojem dostrzegały ustrzymywanie procesów zmian własnościouych. W jednym z artykułów dziennikarka „Życia Warszawy” powątpiewała w słowa premier Hanny Suchockiej o tym, że do 1994 roku połowa majątku

33 J. Lewandouski, Przyszłość jest odgadnięta, PP 2000, nr 43, s. 32-33.

${ }^{34}$ M. Zieliński, Gospodarka 99, PP 1998, nr 39 s. 22-24.

${ }_{35}$ W. Gadomski, Rewolucja liberalna, PP 1991, nr 2/14, s. 8-11; Gra o własność, Rozmowa z J. Lewandowskim, PP 1992, nr 1-2/14-15, s. 66-72.

${ }^{36}$ J. Eysymontt, Zagrożenia transformacji ustrojowej $w$ Polsce, PP 1993, numer specjalny, s. $11-12$.

37 P. Jasiński, Gwiazdy prywatyzacji, PP 1993, numer specjalny, s. 122-129; Stanley Fischer, amerykański ekonomista, uskazywał na prywatyzacyjny konsensus, sprzedaż średnich i małych, komercjalizację dużych i powołanie w nich Rad Nadzorczych, potem ciąg prywatyzacji; Martin Weitzman na stabilne ramy prawne, krytykę konsensusu, prywatyzację polegającą na oddawaniu na własność tym, w rękach których realnie się to już znajduje (pracują tam, zarządzają etc.); John Vickers na wywłaszczenie - nie tylko jako pozbawienie tytułów własności, lecz także zmiana ram prawnych, w jakich owa własność przynosi dochód oraz rozdawnictwo maksymalizujące przychody; Joseph Stiglitz na ekonomiczne i polityczne racje za i przeciu transferowi praw ułasności, odideologizowanie i demitologizowanie mechanizmów rynkouych i prywatyzacji - nie zausze prywatne jest lepsze niż państwowe, zułaszcza duże. Stiglitz polecał rekapitalizouać przemysł, zachować znaczną liczbę akcji przez rząd ze względów fiskalnych. 
zostanie sprywatyzowana. Krytykowała Jana Olszewskiego, który zawiesił prywatyzację pod pretekstem propagandy oczyszczania, a Program Pouszechnej Prywatyzacji (dalej cyt.: PPP) utknął w komisjach. A według niej pouszechna prywatyzacja była najważniejszą, jeśli nie jedyną szansą dla polskiej gospodarkii ${ }^{38}$. W Olszeuskiego uderzył także Lewandouski ówczesny Minister u rządzie Suchockiej, który stuierdził, że wówczas nie było prywatyzacji, a rozdmuchano jedynie nienawiść do niej i do liberałów. Opowiedział się za mobilnym i elastycznym płacowo rynkiem pracy i uznowieniem prywatyzacji ${ }^{39}$. Lewandouski, uspominając uruchomienie giełdy, stwierdzil, że znalazła się w dołku właśnie ze uzględu ustrzymania procesów przekształceń własnościouyych ${ }^{40}$.

Jan Winiecki rozprawiał się z mitami wokół prywatyzacji: wyprzedaży za bezcen, wykupienia przez obcych, o tym że prywatyzacja tonie w korupcji. Uznawał, że biorą się z nieznajomości ekonomii, wartości rynkowych. Ubolewał, że w Polsce najpopularniejsza była prywatyzacja pracounicza - „bolszewicka poprzez „akcjonariat pracouniczy” ${ }^{1}$. Wtórował mu Lewandowski, pisząc o: spisku rządzących, roszczeniach związkowych (twierdząc, że nie ma kraju, gdzie związkowcy mają tyle do powiedzenia o prywatyza$\mathrm{cjil}^{42}$. Podobnie czołowy ekonomista gdański Jan Szomburg narzekał na spowolnienie i załogouy charakter prywatyzacji. Postulował, podobnie jak Lewandowski, wdrożenie u końcu Programu Pouszechnej Prywatyzacji ${ }^{43}$.

W tej materii "dostało" się także koalicji SLD/PSL za spowolnienie reform i tempa zmian $\mathrm{w}$ gospodarce. Zdaniem redakcji władze ustrzymały prywatyzację albo $\mathrm{w}$ jej realizacji przyjęły fiskalne założenia, to znaczy wyprzedawały najlepsze zakłady, aby wyłącznie osiągnąć zyski do budżetu. Andrzej Halicki potwierdził i pochwalił ordoliberalną postawę Lewandouskiego, który, u przeciwieństwie do Wiesława Kaczmarka, ówczesnego Ministra Przekształceń Własnościouych, dbał o zobowiązania inwestycyjne, socjalne i kładł nacisk na ratowanie zagrożonych przedsiębiorstw ${ }^{44}$.

„Przegląd Polityczny” w latach 1993-1997 stał się jednym z głównych rzeczników i obrońców prywatyzacji w wydaniu gdańskich liberałów i jednocześnie oskarżycielem koalicji SLD/PSL za brak profesjonalnie prowadzonych działań na niwie gospodarczej. Znouru był to jednogłos i zabrakło komentarza drugiej strony.

\section{Postulaty reform}

Pierwszym i zasadniczym omówionym ucześniej sposobem realizacji reform gospodarczych była prywatyzacja. Jednakże pozostawał otwarty problem, jak ją przeprowadzić oraz kolejne reformy struktur odziedziczonych po PRL-u.

\footnotetext{
${ }_{38}$ M. Pokojska, Czy prywatyzacja skończy się w tym wieku?, PP 1993, numer specjalny, s. $98-102$.

${ }^{39}$ Własność i rynek, Rozmowa z J. Lewandouskim, PP 1993, numer specjalny, s. 104-107.

40 J. Lewandouski, Gietda w dotku, PP 1993, numer specjalny, s. 130-131.

${ }^{41}$ J. Winiecki, Mit polskiej prywatyzacji, PP 1993, numer specjalny, s. 108-115.

${ }^{42}$ J. Lewandouski, Własność i namiętność, PP 1994, nr 23, s. 78-81.

43 J. Szomburg, Prywatyzacja po wyborach, PP 1993, nr 21/22, s. 82-85.

44 A. Halicki, Prywatyzacyjna batalia, PP 1994, nr 25 s. 54-55.
} 
Lewandowski po raz kolejny analizował ideę bonów uwłaszczeniowych, z realizacji której się jednak wycofał ze względu na ryzyko i wysoką cenę przedsięwzięcia! Zaproponował nowy projekt zmieniający sposób zarządzania przemysłem w postaci funduszy inwestycyjnych tak zwanych zarządców majątku narodowego, które oszczędzałyby i aktyunie działały na rzecz skomercjalizowanego wcześniej przedsiębiorstwa. Byłoby to ustępem do prywatyzacji, a celem była zmiana gospodarza w polskim przemyśle, pobudzenie sprzedaży małych przedsiębiorstu. $\mathrm{W}$ dochodzeniu do gospodarki rynkowej wskazał na interwencję państwa, które skraca drogę do rynku i „wygasa”. Jego zdaniem niemożliue było przejście od komunizmu do państua dobrobytu w stylu skandynauskim, bez epoki liberalizmu ${ }^{45}$.

Szomburg zastanawiał się, jaki model prywatyzacyjny - anglosaski czy europejski - jest dla Polski najlepszy. Oba zależały od adekwatności kulturowej: skłonności do ryzyka (np. Niemcy nie, Amerykanie tak), więzi społecznych (solidaryzm kontra demokratyczny indywidualizm), różnej roli państua, instytucji (większej w Europie). Szomburg, analizując charakter i możliwości Polaków, przybliżył się raczej do modelu anglosaskiego. Twierdził, że Polacy są lepsi u żywiole gry rynkowej, słabi $\mathrm{w}$ instytucjach, uzdolnieniach biurokratycznych ${ }^{46}$. Balcerowicz z kolei opowiedział się za oddzieleniem banków od upływów politycznych i ich prywatyzacjąą, mocnym, stabilnym wymienialnym pieniądzem, wolnością gospodarczą, gospodarką prywatną, rozwojem nie hamowanym przez związki zawodowe i interwencjonizm ${ }^{48}$. Profesor Wacław Wilczyński postulował: przesunąć maksymalizację płac na maksymalizację zysku nadwyżek, restrykcyjną politykę pieniężno-kredytową, suwerenność banku centralnego, a nawet monetaryzm ${ }^{49}$.

Poza tymi ważnymi koncepcjami na łamach „Przeglądu Politycznego” można znaleźć całą masę rad, zaleceń o charakterze liberalnym: zachęcania do inwestycji w Polsce kapitału zagranicznego, likwidowania barier prawnych i administracyjnych ${ }^{50}$, budowaniu rynku kapitałowego, sprzeciw wobec podatku giełdowego ${ }^{51}$, przygotowanie kontyngentów na kredyty dla małych i średnich przedsiębiorstu, pomoc marketingowa dla nich, obniżki stóp procentouych, podatku dochodowego, tworzenie ulg podatkowych nie tylko z tytułu inwestycji, przejrzystość przetargów ${ }^{52}$, wreszcie reformy systemu podatkowego tak, by podatek od towarów i usług móc wliczać w koszty, równość u traktowaniu przez fiskusa prywatnych i państwowych przedsiębiorstw, eliminować tych, co nie spłacają kredytów, zobowiązań etc.

${ }_{45}$ Gra o własność, Rozmowa z J. Lewandowskim, PP 1992, nr 1-2/14-15, s. 66-72. Szczegółowe zasady programu zwanego NFI omówił A. Halicki, Na skróty do nowoczesności, PP 1994, nr 25, s. 64-65.

46 J. Szomburg, Jaki kapitalizm, PP numer specjalny 1993, s. 3-10.

${ }^{47}$ L. Balcerowicz, Demokracja nie zastapi kapitalizmu, PP numer specjalny 1993, s. 24-31.

${ }^{48}$ L. Balcerowicz, Kapitalizm i jego fundamenty, PP 1994, nr 25, s. 36-37.

${ }^{49}$ W. Wilczyński, Dylematy antyrecesyjnej polityki pieniężno-kredytowej, PP 1993, numer specjalny, s. 64-68.

${ }_{50}$ M. Górski, Inwestycje zagraniczne w Polsce, PP 1993, numer specjalny, s. 116-120.

${ }^{51}$ L. Paga, Prawa jak z Biblii, PP 1994, nr 26, s. 38-39.

${ }^{52}$ M.H. Grabouski, P. Kulawczuk, Polski Sektor Prywatny, op. cit., s. 66-70. 
„Przegląd” usparł także ideę Kongresu Liberalno-Demokratycznego (KLD) paktu z kapitałem ${ }^{53}$. Szomburg po raz kolejny wzywał do reform strukturalnych „skansenu” odziedziczonego po PRL-u: edukacji (wprowadzając bon edukacyjny, sprywatyzować ośrodki badauczo-naukowe), służby zdrowia, ubezpieczeń społecznych, restrukturyzacji rolnictua, przemysłu, likwidacji bezrobocia. Szansę dostrzegł w rozwoju sektora usług i jej przebudowie ${ }^{54}$. „Przegląd” zawarł kilka wypowiedzi przeciwko paktowi o przedsiębiorstuie państwourym zaproponowanym przez rząd Suchockiej ${ }^{55}$. Na potwierdzenie obaw, czy reformowanie polskiej gospodarki idzie w dobrą stronę, przytoczono sondaż PBS dotyczący pytania: Czy w Polsce jest klimat do robienia interesów. Tylko 10\% respondentów odpowiedziało tak ${ }^{56}$.

Wzorem do naśladowania politycznego była syluetka Margaret Thatcher, która odcisnęła w jakiejś mierze sue piętno na obliczu polskiego programu transformacji ustrojowej i radykalnej terapii57. Zamieszczono fragment jej wypowiedzi: „Polityczną podstawą demokracji jest silny ograniczony rząd, podlegający systematycznej ocenie uyborców a nade uszystko rządom prawa"58, co wpisało się w koncepcje gdańskich liberałów.

Apele „Przeglądu Politycznego” zyskały swoistą autoryzację dzięki wypowiedziom wielu czołowych uczestników życia gospodarczego Polski - właścicielom dużych i średnich przedsiębiorstw, fundacji, stowarzyszeń. „Przegląd” zajął się promocją sukcesu i pokazywaniem tych, którym się udało. Potrzeba nam propagandy sukcesu! - pokazywać tych, którym się powiodło - wzywał dyrektor ICI Poland ${ }^{59}$. Prezes Agrosu apelowała, aby Polacy sami sobie pomogli, reformując gospodarkę, by w ten sposób być atrakcujnym miejscem dla kapitału zagranicznego, a także zmienić system podatkowy - uprościć, tworzyć strefy szczególnego zagrożenia bezrobociem ${ }^{60}$. Szef Business Centre Club Maciej Goliszewski wyszedł z inicjatywą wprowadzenia do sejmu 50 posłów o poglądach liberalnych ${ }^{61}$. Zbigniew Niemczycki zwracał uwagę na

${ }_{53}$ M.H. Grabouski, P. Kulawczuk, Dlaczego pakt z kapitatem?, PP 1993, numer specjalny, s. 56-59; też W. Gadomski, Szukając zadowolonych, PP 1993, numer specjalny, s. 15-17. KLD zaproponowało specjalne kredyty inwestycyjne, zwiększenie zdolności guarancyjnych polskich instytucji, stabilność prawa gospodarczego.

54 J. Szomburg, Czas na nowy impuls, PP 1995, nr 27/28, s. 39-42.

55 J. Lewandowski, Potrzeba strategii gospodarczej, PP 1994, nr 25, s. 45-47: „Nie wierzę w scentralizowane pakty torujące drogę do bolesnych zmian w poszczególnych sektorach gospodarki. [...] Sednem paktu są koncesje i przywileje, które mają okupić pokój społeczny i przyzuolenie na zmiany. Celem jest strategia: korekta, a nie utwierdzanie socjalistycznych naleciałości"; też J. Pańkow, Pakt i co dalej, PP 1993, nr 21/22, s. 85.

${ }_{56}$ Sondaż PBS „Rzeczpospolitej” dla menedżerów, PP 1993, numer specjalny. Sondaż uskazał na bariery u dobrym klimacie inuestycyjnym: zmienność przepisów, wysokie podatki, inflacja, słabe banki, brak kapitału.

${ }^{57}$ W. Wilczyński, Siła i skuteczność, PP 1997, nr 33/34, s. 14.

${ }^{58}$ Ibidem, s. 20.

59 J. Kluk, PP 1993, numer specjalny, s. 54.

${ }^{60}$ Wypowiedź Z. Gaber-Sobieralskiej dyrektora Agros-u, PP 1993, numer specjalny, s. 49.

${ }^{61}$ Rozmowa z M. Goliszewskim z BCC, PP 1993, numer specjalny, s. 18. 
polskie lokomotywy - przemysł lekki i rolno-spożywczy ${ }^{62}$. Znalazły się także mało liberalne postulaty wzywające do interwencjonizmu w rolnictwie ${ }^{63}$. Przyszły aferzysta gospodarczy Jerzy Leksztoń narzekał na niestabilne przepisy i nomenklaturowe banki ${ }^{64}$.

Jedną z najważniejszych organizacji dla środowiska „Przeglądu Politycznego” był współtuorzony przez gdańskich liberałów Instytut Badań nad Gospodarką Rynkową Pismo promowało i patronowało działalności IBNGR, prezentując wypowiedzi członków Instytutu, reklamując go na swoich stronach. Jednym z najczęściej publikujących autorów był prezes Instytutu Jan Szomburg ${ }^{66}$.

Na zakończenie warto uspomnieć o kluczouym zagadnieniu dla gdańskich liberałów, czyli o decentralizacji. Jan Krzysztof Bielecki czy Lech Mażeuski snuli plany dużych autonomicznych regionów, wyposażonych w szerokie kompetencje i budżet ${ }^{67}$. Samorząd lokalny miał być szkołą społeczeństwa obywatelskiego i jak napisał Balcerowicz: „instytucjonalną kotwicą stabilności” z apolityczną i fachową administracją ${ }^{68}$. Upadek rządu Suchockiej spowodował niemożność realizacji tych koncepcji. Redakcja nie mogła znieść, że SLD i PSL w sprawie reformy terytorialnej nic nie robią i ogłosiła wręcz „bunt prowincji” (taki tytuł miał numer 29 z jesieni 1995, a przez kilka numerów pojawiał się na łamach pisma dział o tym tytule), przystępując do ofensywy na rzecz decentralizacji państwa. Tusk, narzekając na centralne sterowanie i nieufność do idei regionalizacji, oświadczał, że: „Bunt prowincji to nie irredenta, a chęć uniezależnienia się od stołecznego centrum, nie od reszty kraju" ${ }^{\prime 9}$. Rzucił hasło dyskusji, która odtąd stale toczyła się na łamach pisma i która odżyła przed uyborami w 1997 roku. Ponownie debatowano o reformie samorządowej i związanym z tym nowym podziale terytorialnym kraju. Ponownie pojawiło się hasło 12 województw ${ }^{70}$.

\section{Rozliczenie z liberalną rewolucją}

Bardzo szeroko dyskutowana była klęska centroprawicy w wyborach z 1993 roku, w tym szczególnie KLD. Poszczególni członkowie partii prezentowali swoje wypowiedzi na ten temat. W rozmowie redakcyjnej Tusk stwierdzał, że klęskę spowodowały bieda, poczucie zawodu, kryzys marzeń społecznych i wynik ogromnych oczekiwań społecznych.

\footnotetext{
${ }^{62}$ Ibidem, s. 59.

63 R. Młyniec (prezes Rolimpexu), Konieczny interwencjonizm, PP 1994, nr 25, s. 41.

64 J. Leksztoń, Bitwa o kapitalizm, PP 1993, numer specjalny, s. 103.

${ }^{65}$ Instytut został założony 2 grudnia 1989 roku przez Janusza Lewandouskiego i Jana Szomburga, który jest od początku prezesem IBNGR. Początkowo był fundacją, która poprzez publikacje naukowe, organizację seminariów, konferencji, debat, miała uspierać proces transformacji polskiej gospodarki i państwa. Obecnie jest obywatelskim think-tankiem skierowanym w stronę przyszłości i rozwoju Polski, http://www.ibngr.pl/O-Instytucie (dostęp 28.09.2018).

${ }_{66}$ Rozmowa z J. Szomburgiem, Prywatyzacja nauki - pierwszy krok w Gdańsku, PP 1991, nr 2/14, s. 17-19.

${ }^{67}$ L. Mażeuski, Wzmocnienie państwa, PP 1992, nr 17, s. 73-76.

${ }^{68}$ L. Balcerowicz, Demokracja nie zastapi kapitalizmu, PP 1993, numer specjalny, s. 24-31.

${ }^{69}$ D. Tusk, Bunt prowincji, PP 1995, nr 29, s. 55.

${ }^{70}$ B. Jałowiecki, Nowa regionalizacja, PP 1996, nr 32, s. 35-42.
} 
Ubolewał, że pomimo owocnej restrukturyzacji polskiej gospodarki, zabrakło zmian w mentalności. Szef KLD odsłonił kulisy przeduyborczych rozmów, próbujących utworzyć koalicję wyborczą Kongres Liberalno-Demokratyczny-Unia Demokratyczna (KLD-UD). Tusk rysował plany budowy nowej siły politycznej sojuszu obu partii, który według niego był przymusem. W innym razie groziło im obumarcie: „Dziś ani UD, ani Kongres nie mogą być przeciuwagą dla socjalistycznych żywiołów" ${ }^{11}$.

Na łamach pisma dokonywała się także „samokrytyka” czy rozliczenia efektów politycznej działalności KLD. Paweł Śpiewak pisał, że liberałowie zamknęli się w języku gospodarki - pojęć i uskaźników, wzywali do wyrzeczeń, do wzięcia sprawy u swoje ręce, bycia przedsiębiorczym. Ale z przetłumaczeniem liberalnego programu na język ludzki było sporo kłopotów. Nie przekonywano ludzi, wręcz zniechęcano do polityki liberalnej. I tak zrodziły się podejrzenia o „przekręty”, wyprzedaż majątku narodowego. Autor zarzucił im brak reformy państwa, niestworzenie dobrego klimatu do robienia interesów, zaniechanie reformy edukacji. Śpiewak przypomniał stare powiedzenie, że rewolucja pożera własne dzieci: „Zapomnieli (liberałowie), że poza rozsądkiem i prawdą są jeszcze interesy życiowe, ludzkie namiętności, ambicje, stare nawyki. Przegrali, wierząc u nadrzędność ekonomiczną i jej sprawczą rolę"72.

Krzemiński zurócił również uwagę na niewłaściwą komunikację. Przyczyny klęski obozu reform wiązał z kuestiami złej promocji i informacji, ale i problemami bezrobocia, pozostawienia Państwowych Gospodarstu Rolnych (PGR-ów) ${ }^{73}$. W podobnym duchu pisał John Terry, dodając do tego słabość partii i liderów na prawicy oraz nową ordynację z progami i przeliczeniami metodą d'Hondta premiującą silniejszych ${ }^{74}$. Próbą polemiki z zarzutami był tekst Lewandouskiego o buncie mas. Pisząc o peunym fatalizmie uskazał, że nic nie odmieniłoby losu liberałów, ponieważ nie uzyskali oni usparcia telewizji, Solidarności. Do tego doszło „awanturnictuo” części prawicy, potępianie „w czambul” czterech lat reform. Lewandowski oparł się na tradycyjnej już niechęci liberałów do opinii publicznej, która ,jest raczej uytworem zbiorouych emocji, a nie uogólniania faktów”, a „W kręgu stereotypów i obiegowych opinii zręczna propaganda ma większy sens niż logiczna argumentacja" ${ }^{2}$.

Podobnie jak u przypadku prezentowania ideologii liberalnej, również i „rozliczenie z liberalną rewolucją" dokonuje się dosyć szybko. Oba tematy stopniowo zanikają gdzieś od roku 1994. W numerze 25 zaprezentowano jedną z ostatnich dyskusji gdańskiego środowiska oraz tekst prof. Jerzego Szackiego na temat liberalizmu ${ }^{76}$. Profesor przypomniał, że istnieją dwa liberalizmy: polityczny (styl odczuwania, myślenia) i ekonomiczny. Z żalem stwierdzil, że w Polsce żadna z tych koncepcji liberalnych nie jest bliska realizacji. Lewandowski ubolewał, że reformy gospodarcze nie zostały

\footnotetext{
${ }^{71}$ Rozmowa W. Dudy z D. Tuskiem, Demokracja Polska, PP 1993, nr 21/22, s. 7-13.

${ }^{72}$ P. Śpiewak, Liberałowie po latach, PP 1993, nr 21/22, s. 14-16.

${ }^{73}$ I. Krzemiński, Czy zwyciężyt socjalizm, PP 1993, nr 21/22, s. 17-19.

74 J.A. Terry, Trzecia Rzeczpospolita skręca w lewo, PP 1993, nr 21/22, s. 21-25.

75 J. Lewandouski, Sztafeta liberałów i bunt mas, PP 1994, nr 26, s. 86.

76 J. Szacki, Liberalizm po komunizmie, PP 1994, nr 25, s. 4-11.
} 
wsparte etosem liberalnym. Tusk nieco optymistyczniej podsumouywał: „Politycznie liberałowie przegrali, ale śladów naszej pracy nie musimy się ustydzić”, choć podszedł też samokrytycznie do swojej działalności: „Uznaliśmy, że sam dar wolności powinien obudzić optymizm. Ale zapomnieliśmy o sprawach oczywistych, że ucieczka od wolności tez jest stanem naturalnym"77.

Po latach pismo zamieściło gorzką refleksję Lewandouskiego na temat zachodniej socjaldemokracji Tony Blaira i Gerharda Schroedera, w której odnalazł on swoje idee, ale: „ten liberalizm gospodarczy, opakowany zręcznie $w$ frazeologię społecznej sprawiedliwości, stał się poszukiwanym towarem na europejskim rynku wyborczym, tyle, że nie poprawia to w żadnym stopniu kondycji politycznej samych liberałów"78. Pałeczkę w sztafecie liberalnej rewolucji przejęli socjaldemokraci zachodni, którzy w umiejętny sposób odwoływali się do nastrojów społecznych. Była to cenna lekcja, jak uspółcześnie należy sobie radzić z adaptacją liberalnych idei i jednocześnie gorzka pigułka dla promotorów liberalnej rewolucji w Polsce.

\section{Podsumowanie}

Wielokrotnie na łamach „Przeglądu Politycznego” poutarzano o sukcesach polskiej transformacji: najbardziej zdemopolizowanym i konkurencyjnym rynku towarów i usług w Europie Wschodniej, malejącej inflacji, wymienialnej walucie, liberalizacji handlu zagranicznego, boomu w rozwoju przedsiębiorstu prywatnych, prywatyzacji. Lewandowski uspominał jako swój sukces uruchomienie giełdy warszawskiej, co stanowiło podręcznikowy przykład nadrobienia 50-letniej cywilizacyjnej luki i realizacji idei liberalizmu konstruktywistycznego ${ }^{79}$.

„Przegląd Polityczny” nieustannie wzywał do liberalnej czujności. Ostrzegano przed brakiem reform w służbie zdrowia, oświacie i ubezpieczeniach społecznych, reform podatkowych, prywatyzacji banków, anarchii zuiązków zawodowych, rozdrobnieniu sceny politycznej ${ }^{80}$. Wzywano do determinacji w działaniach, by nie zaprzepaścić dorobku reformatorskiego ${ }^{81}$. Balcerowicz przypominał, że nie ma żadnej korelacji między demokracją a postępem gospodarczym, demokracja zaś bez kapitalizmu może być zagrożona ${ }^{82}$. Z kolei Szomburg ostrzegał, że czas prostych działań, reform minął i trzeba reformować oświatę, służbę zdrowia, ubezpieczenia społeczne, kontynuować przemiany prywatyzacyjne. W obliczu zbliżających się wyborów w 1997 roku nakreślił

\footnotetext{
77 Ibidem, s. 6-9.

78 J. Lewandowski, Trzecia droga gorzka satysfakcja liberała, PP 1999, nr 42, s. 37.

79 J. Lewandouski, Gietda w miejsce KC PZPR, PP 1996, nr 31, s. 38-42. Choć prezes giełdy przypomniał o niespełnionym marzeniu byłego ministra, który pragnął utuorzenia ośrodków regionalnych. Niestety ze względu na brak czasu, na spontaniczny rozwój giełd w Europie Środkowej i Wschodniej oraz centralizacyjne tendencje w świecie, wybrano inny model. Rozmowa z Wiesłauem Rozłuckim, PP 1996, nr 31, s. 43-46.

${ }^{80}$ M. Dąbrouski, Bilans trzech lat, PP 1993, numer specjalny, s. 13-14.

${ }^{81}$ M. Wojtczak, Porzaddkowanie polskiej gospodarki, PP 1993, numer specjalny, s. 19-20.

${ }^{82}$ L. Balcerowicz, Demokracja nie zastapi kapitalizmu, PP 1993, numer specjalny, s. 24-31.
} 
sojusz Polski tradycyjnej - katolickiej i liberalnej, zapytując o wielkość potencjału prorynkowego u opcji katolickiej. Zalecał porozumienie stron katolickiej i liberalnej, które umożliwiłoby szybki marsz do dojrzałej gospodarki rynkowej. Duże nadzieje wiązano z sojuszem AWS i UW oraz przejęciem przez nie rządów ${ }^{83}$.

Jednym z ciekauszych artykułów, który ukazał się w roku 2000, jakby na podsumowanie liberalnej rewolucji, był tekst Zielińskiego, który gruntownie skrytykował koncepcje uwłaszczeniowe i Program Pouszechnej Prywatyzacji Lewandouskiego. Sam zaś pomysł Narodowych Funduszy Inwestycyjnych (NFI) określił jako zły. Uważał bowiem, że nie da się przyspieszyć procesów nie do przyspieszenia, sztucznie kreować właściciela, który chce zysku, a nie rozwoju firmy ${ }^{84}$. Dziś z perspektywy czasu możemy powiedzieć, że miał rację.

Jak zatem przedstawia się 10-letni dorobek liberalnej rewolucji na łamach „Przeglądu Politycznego". Mamy dua wymiary tej rewolucji: teoretyczny i praktyczny. Od 1983 roku rozwijano myśl liberalną, kształtowano kanon wartości liberalnych, ostatecznie określoną jako liberalizm konstruktywistyczny ${ }^{85}$. W tej koncepcji te dwa wymiary liberalizmu ostatecznie się połączyły. „Przegląd Polityczny” starał się tworzyć polski wzorzec $\mathrm{w}$ drodze do kapitalizmu, do budowania gospodarki rynkowej w warunkach kraju postkomunistycznego. Analizował dorobek reformatorski, przedstawiał konkretne rozwiązania. Widać, jak w centrum zainteresowania liberałów znalazła się prywatyzacja jako remedium wielu problemów. Czasopismo starało się być obrońcą przeciuko oskarżeniom skierowanym pod jej adresem i pod adresem autorów przemian, obalało mity na temat prywatyzacji. Promowano też Program Pouszechnej Prywatyzacji autorstwa Janusza Lewandouskiego. Zresztą Lewandowski, oprócz tego, że był czołouym ideologiem liberalnym w latach 80 . XX wieku, to miał w latach 90. jako polityk, minister, okazję do realizacji i udrożenia liberalnych rozwiązań. Był najczęściej cytowanym i prezentowanym politykiem na łamach „Przeglądu Politycznego”, stając się najważniejszym liberalnym autorytetem.

Na łamach „Przeglądu Politycznego" nie doszło jednak do opracowania jasnego i konkretnego programu gospodarczego - całościowej wizji liberalnej. Poza promocją dokonań Lewandouskiego, promocją kilku jego propozycji doskwierał brak spójności kilkuset uypowiedzi różnych osób (też gdańskiego środowiska), które stanowiły jakby rozrzucone postulaty, problemy do analizy. Ten natłok spowodował zamknięcie publicystyki ue własnym kręgu, kierowanie się do wąskiej grupy docelowej przedsiębiorców, ludzi, którzy poradzili sobie w okresie transformacji, czy liberalnych intelektualistów, naukouców, myślicieli, ekonomistów. „Przegląd Polityczny” pozostał pismem elit dla elit.

\footnotetext{
${ }_{83}$ J. Szomburg, Bariery dalszych reform, PP 1996, nr 32, s. 32-36.

${ }^{84}$ M. Zieliński, Koniec pewnego mitu, PP 2000, nr 46/47, s. 22-24. Autor opisał róunież przykład prywatyzacji czeskiej - kuponowej, która jego zdaniem spowodowała, że: „struktura własnościoua okazała się hybrydą opartą na zawiłej sieci własności pochodnej banków i państwouych funduszy - była w istocie kryptorenacjonalizacją".

${ }^{85}$ Por szerzej: K. Knoch, „Przegląd Polityczny” w latach 1989-2000. Cz. 2. Liberalna rewolucja, „Media Biznes Kultura” 2018, nr 4, s. 105-106.
} 
Zabrakło klarownego programu, podobnie jak $\mathrm{w}$ drugim obiegu. W wielu miejscach były to ogólnikowo rzucane hasła. Ryszard Skarzyński czyni z tego zarzut liberałom ${ }^{86}$. Czy jest on jednak sprawiedliwy? Jeśli przyjąć, że „Przegląd Polityczny” nie stanowił organu partyjnego, to nie. Nie musiał więc przedstawiać konkretnych projektów, programów, gdyż nie był miejscem dla partyjnych inicjatyw czy dziennikiem ustaw. Udostępniał swe łamy wielu osobom, które zdaniem redakcji miały coś ciekawego do powiedzenia na tematy gospodarcze, liberalne. Wydaje się, że miał być swoistym forum liberalnym czy miejscem ożywionej debaty, dyskusji o problemach gospodarczych Polski, przestrzenią, gdzie mogły uypowiedzieć się dziesiątki publicystów, naukowców, filozofów, ekonomistów na tematy wolnorynkowe. Miał przede uszystkim inspirować, zaszczepiać pewne idee i pomysły.

W sumie jednak to forum było dość jednostronne. Z rzadka na łamach „Przeglądu Politycznego" gościli przeciunicy liberalizmu, a głosów krytycznych zamieszczano jak na lekarstwo. Najczęściej sami liberałowie po części składali samokrytykę, a po części bronili dorobku obozu reform. W swoich analizach nie doceniali czynnika ludzkiego, skutków społecznych. Pisano raczej o gospodarce, liczbach, zjawiskach. Temat bezrobocia, PGR-ów czy społecznych konsekwencji reform u zasadzie nie występuje. A jeśli już, to liberałowie mieli sprzyjać stuorzeniu klasy średniej, dokonywać selekcji i organizowania zadowolonych $-1,5$ miliona drobnych przedsiębiorców ${ }^{87}$. Od tego, czy szybciej będzie powiększać się grupa beneficjantów transformacji, zależał los polskich reform $^{88}$. I w zasadzie los ruchu liberalnego w Polsce. Społeczeństwo traktowano dość utylitarnie.

W latach 1991-1994 śmiało można uznać pismo za silnie zaangażowanie w politykę i próbujące odgrywać rolę forum - spotkania tendencji liberalnych i konserwatywnych, dyskusji o modelu polskiej gospodarki. Było swoistym zapleczem intelektualnym obozu reform gospodarczych. I chociaż próbowało otwierać się na centroprawicę, stanowić miejsce szerszego spotkania poglądów prawicouych, to moim zdaniem próba ta się nie powiodła. Poza tym lewicowe rządy SLD-PSL są krytykowane bardzo mocno, w zasadzie odbiera się im prawa do obrony. Na łamach „Przeglądu Politycznego” nie ma polityków tych partii, nie ma lewicouych autorytetów. Natomiast, co ciekawe, w momencie objęcia władzy przez rząd AWS/UW, czyli w części przez ludzi związanych niegdyś z KLD, głosy krytyczne i analityczne milkną. Próżno szukać wiadomości na temat głośnych reform strukturalnych, które podjęła koalicja, poza tym, że powinny one być. Zabrakło charakterystyki zmian. Skromnie w dziale „Gospodarka” dokonywano niedużych podsumowań. Być może milczenie oznaczało zgodę-akceptację. Być może „Przegląd Polityczny” nie chciał utrudniać kolejnego etapu liberalnej rewolucji, wikłając

${ }_{86}$ R. Skarzyński, Pomiędzy radykalizmem a konserwatyzmem. Gtówne idee polityczne gdańskich liberałów i KL-D w latach 1983-1992, „Studia Polityczne” 1994, nr 3.

${ }_{87}$ W. Gadomski, Szukając zadowolonych, PP 1993, numer specjalny, s. 15-17; też Rozmowa z A. Rychardem, Świat wypadt z zawiasów, PP 1993, numer specjalny, s. 74-78.

${ }^{88}$ D. Filar, Beneficjanci i pauprowie albo polski wyścig, PP 1993, numer specjalny, s. 69-73. 


\section{Konrad Knoch}

się w szczegółową debatę o charakterze krytycznym. Być może świadomie, ze względu na złe konotacje, unikano utożsamiania reform z programem liberalnym?

Wskutek trudności finansowych w latach 1993-1994 nastąpiło stopniowe odejście od idei pisma politycznego, wewnątrzśrodowiskowego ${ }^{89}$. Pojawiło się otwarcie na regiony, Polskę autonomiczną, decentralizację, budowę społeczeństua obywatelskiego. Zmiana u retoryce „Przeglądu Politycznego” była zuiązana róunież z klęską wyborczą obozu reform u 1993 roku, zanikiem formacji politycznej KLD i wreszcie objęciem władzy przez koalicję AWS-UW. Przełom 1995/1996 to już wyraźna ewolucja pisma. Warto przytoczyć wypowiedź Wojciecha Dudy, która trafnie obrazuje jego zmiany profilowe:

Przestałem myśleć o «Przeglądzie» jako piśmie politycznym. Stał się dla mnie magazynem, gdzie spotyka się: polityka, kultura, historia. «Przegląd» stał się almanachem, gdzie nie rezygnując z tożsamości liberalnej, liberalno-konserwatywnej, na czoło wysuwają się tematy ważne dla nas, z którymi byśmy chcieli się podzielić z innymi ${ }^{90}$.

A pismo od tej pory dzieliło się szerzej tematyką Gdańska, globalizacji (problematyki stosunków międzynarodowych), lustracji i wreszcie kultury czy literatury.

Zmieniło się też podejście do ludzi. Początkowo pesymistycznie spoglądano na Polaków, na mentalne dziedzictuo PRL-u, pojauiała się nieufność pod adresem społeczeństwa. Stopniowo przestaje być ono jedynie utylitarnym narzędziem, a „Przegląd Polityczny" uspiera rozwój społeczeństwa obywatelskiego i wielokrotnie promuje oraz definiuje to pojęcie ${ }^{91}$. Przytoczone przykłady pokazują, jak gdańskie środowisko dojrzewało i potrafiło prezentować program pozytywny.

Na koniec nasuwa się jeszcze jedna refleksja. Na łamach „Przeglądu Politycznego” nic nie znajdziemy o Wybrzeżu - gospodarce czy polityce morskiej, nie ma prawie nic o przemyśle stoczniouym, rybołóustuie. Dominują teksty na temat historii czy tożsamości Gdańska. Z rzadka mamy jednak połączenie Gdańska i liberalizmu, choć sporo pisano o koniecznych zmianach w mieście ${ }^{92}$. Nie dowiemy się, jak ten duch

${ }^{89}$ Por szerzej: K. Knoch, „Przeglad Polityczny” w latach 1989-2000. Cz. 1. Problemy organizacyjno-wydawnicze, „Media Biznes Kultura” 2017, nr 2(3), s. 57-70.

${ }^{90}$ Relacja W. Dudy złożona K. Knochowi u 2002 roku.

${ }_{91}$ Por szerzej: A. Siciński, Spoteczeństwo obywatelskie, PP 1997, nr 33/34, s. 86-89; J. Szacki, Społeczeństwo obywatelskie, PP 1996, nr 32, s. 50-53; A. Rychard, Społeczeństwo, państwo, rynek, PP 1996, nr 32, s. 48-49; J. Gray, Jutro społeczeństw, PP 1997, nr 33/34, s. 113-118.

${ }_{92}$ Za kluczowe uznano budowę autostrady A1 i w ogóle rozwój komunikacji, uspółpracę w euroregionie Bałtyku, ponadto restrukturyzację i prywatyzację, tworzenie miejsc pracy, promocję turystyki, ekologię, bezpieczeństwo, przezwyciężenie kryzysu finansowego służby zdrowia, nacisk na rozwój oświaty, promocję kultury Kaszub i Kociewia. W strategii dla Gdańska stawiano na turystykę, ale i dbałość o edukację. Były to cenne, ale niestety dość ogólnikowe hasła, poruszające uszystkie najważniejsze problemy miasta (zresztą uniwersalne dla każdego innego). Wrzucono uszystko do jednego worka, ale nie podano żadnych perspektyw czasouych, nie zarysowano, jak tego uszystkiego dokonać, nie podano źródeł finansowania projektów. Pismo ułączyło się także na chwilę $\mathrm{w}$ dyskusję na temat konkurencji między portami gdyńskim i gdańskim. Filar uzywał do budowy jednego portu Trójmiasto. Rzecznik prasowy portu gdańskiego uyjaśniał, że nie należy traktować rozbudowy portu w Gdyni i w Gdańsku jako 
liberalny ma się realizować w wymiarze lokalnym, z uwzględnieniem lokalnej specyfiki. To swoiste odwrócenie od morza w wymiarze ekonomicznym jest chyba największym paradoksem gdańskiego liberalizmu.

\section{Bibliografia}

\section{Źródła}

„Przegląd Polityczny” 1991-2000, nr 13-46.

Relacja złożona K. Knochowi przez Wojciecha Dudę, 2002.

\section{Artykuły}

Knoch K., „Przeglad Polityczny” w latach 1989-2000. Cz. 1. Problemy organizacyjno-wydawnicze, „Media Biznes Kultura” 2017, nr 2(3), s. 57-70.

Knoch K., „Przeglad Polityczny” w latach 1989-2000. Cz. 2. Liberalna rewolucja, „Media Biznes Kultura" 2018, nr 1(4), s. 97-109.

Szczepański D., Geneza powstania partii politycznej na przykładzie Kongresu Liberalno-Demokratycznego (1983-1990), „Polityka i Społeczeństwo” 2009, nr 6, s. 103-112.

Skarzyński R., Pomiędzy radykalizmem a konserwatyzmem. Główne idee polityczne gdańskich liberałów i KL-D w latach 1983-1992, „Studia Polityczne” 1994, nr 3.

\section{Opracouania}

Knoch K., Pisma liberalne drugiego obiegu w latach 1979-1990. Instytut Pamięci Narodowej, Warszawa 2015.

Szacki J., Liberalizm po komunizmie, Znak, Kraków 1994.

Teczki liberałów, skompletowali J. Paradouska, J. Baczyński, Wydawnictwo Obserwator, Poznań 1993.

Tusk D., Idee gdańskiego liberalizmu, Fundacja Liberałów, Gdańsk 1998.

rywalizacji, każdy z nich ma bowiem swoje zadania. Por szerzej: J. Lewandouski, T. Parteka, D. Sobczak, W. Toczyski, Strategia 2000 plus rozwoju województwa gdańskiego, PP 1997, nr 33/34, s. 90-99; J. Lewandowski, Strategia rozwojowa Gdańska, PP 1998, nr 37/38, s. 106-107; PP 1998, nr 37/38, s. 110-111; PP 1998, nr 39, s. 114. 